glad to forward, in the name of the individual donor, any contribution toward this homage from all the enlightened world to one of the foremost names in " the pedigree of human thought."

2407 Guadalupe Street, Austin, Texas.

George Bruce Halsted.

\section{Nesting of the Road-Runner.}

THIS very peculiar long-tailed bird is common here throughout the year. It inhabits mainly the broad arroyos cosered with chapparal thickets and scrub-oaks, as here is found its principal food, small snakes and lizards. The breeding season is from the middle of March to the last of July. The number of eggs laid varies in this locality from three to nine, though usually four to seven. The eggs are pure white, covered with a thick chalky coating which is of ten found partly scratched off.

The nests are built in thick chapparal bushes or scrub oaks. from two to five feet from the ground. They are composed of coarse sticks placed roughly across the supporting branches to the thickness of about two inches and a diameter of ten inches. Over this platform is placed a layer of sage leaves and twigs, forming a shallow, saucer-shaped depression. Then last, but invariably, is placed in the depression a small amount of dry horse-manure broken into small pieces. I do not know the reason of this last addition but it is nevertheless an invariable constituent of the Road-Runner's nest

The nest of the Burrowing Owl presents the same peculiarity, though with an apparent reason. The nest cavity of the Bur. rowing Owl is always partly filled with green horse-manure. In this case the decaying vegetable matter probably forms heat enough to carry on the incubation. But in regard to the RoadRunner's nest I do not see the necessity of the dry horse-manure.

I would be pleased to hear from any one who is acquainted with the nesting habits of the Road-Runner. JoE GrinNelL.

Pasadena, Cal.

\section{Ad Ignorantiam.}

THE calumniators of Professor Wright have been fully met, and an animus for their attack suggested. There are some critics remaining who have used an argument not found in logic,- that "ad ignorantiam," - with freedom, and, to the users, with telling effect. A few words as to this argument may not be inopportune.

A. can neither recognize the peculiarly shaped pinnacles on the top of a glacier from day to day, nor can he remember the names of the people who are introduced to him at the receptions to which he goes. B. can do both readily, and states his ability to do so. Thereupon C. jumps up and says that it is impossible to B. to speak the truth, as it is notorious that $A$. can do neither, and $A$. is an authority on all subjects. A. finds it impossible on Monday to stake out the surface of a slippery sidewalk, and publishes the fact. On Tuesday B. comes along with knit socks over his boots and makes that sidewalk look like a dress-maker's pincushion. When this fact is published, the ubiquitous $C$. springs up and tells how of ten the frame of A. subsided in the attempts, and therefore $B$. never did what he claims to have done.

A whole tribe of A's fail to find Truth at the bottom of the wellall old authorities to the contrary notwithstanding - and thereupon dogmatize to the effect that she is not there or, if there, is a palimpsest edition, introduced by ex-Olympian means. When $B$. shins down the rope and brings up the damp and coy dame, he is met by shrieks of $\mathrm{C}$., to the effect that he carried her down in his pocket, because all the A's., aided by the strongest microscopes, could not locate her within seven rows of apple trees of the place.

It may strike people as rather funny for men who have said that certain things do not exist, to prove that they do not exist by failing to find them. It is not their business to find them, or, rather, it would seriously hurt their business to find them. They cannot adduce their ignorance or inability against the knowledge and power of others who have done what they have failed to do, and what they wished to fail to do.

The writer does not think many of the questions as fully settled as they might be; but he does not propose to believe a man because he poses as an ignoramus.

Bethlehem, Penn., April 14. EDWARd H. Williams, JR.

\section{Color in Flowers.}

IN reply to the inquiry on p. 179 will say that the preserration of colors in flower is fully explained in Professor Bailey's "Horticultural Rule Book."

F. H. Plumb.

Springfield, Mass., April 20.

\section{BOOK-REVIEWS.}

Idle Days in Patagonia. By W. H. Hudson. New York, D. Appleton \& Co., VIII. 256 p. $8^{\circ}$.

THE author of "The Naturalist in La Plata," reviewed on a previous occasion in these columns, has given us in the present volume another interesting book. At first sight the title seems somewhat misleading, inasmuch as the author met with an accident a few days after his arrival in the country and was confined to the house for a considerable period. As, however, he says the book would probably never have been written if the original intentions in visiting the country bad been carried out, we may consider the accident a lucky one. His "Idle Days" gave him ample time for thought, and in this as in the previous volume we have many original ideas. The most of the time was spent in the valley of the Black River, and in his chapter upon the valley we note a fact that may be of interest at the present time in view of the controversy going on in relation to palæolithic man in America. In wandering along the banks of the stream he found many arrowheads on the ancient village sites. They were of two widely different kinds, "the large and rudely fashioned, resembling the palæolithic arrowheads of Europe, and the highly-finished, or neolithic arrowheads of various forms and sizes, but in most specimens an inch and a half to two inches long. Here there were the remains of the two great periods of the Stone Age, the last of which continued down till the discovery and colonization of the country by Europeans. The weapons and other objects of the latter period were the most abundant, and occurred in the valley: the ruder and more ancient weapons were found on the hillsides, in places where the river cuts into the plateau. The site where I picked up the largest number had been buried to a depth of seven or eight feet; only where the water after heavy rains had washed great masses of sand and gravel way, the arrowheads with other weapons and implements had been exposed. These deeply buried settlements were doubtless very ancient."

He found that to the inhabitants of the valley, the river was all in all. Beyond its banks spread the gray, desolate desert; within the valley's bounds were light and life. Just as all things were mirrored in its waters, so was the stream reflected in the minds of the people. "Even the European colonists," says he, "have not been unaffected psychologically by the peculiar conditions they live in, and by the river on which thay are dependent. When first I became cognizant of this feeling, which was very soon, I was disposed to laugh a little at the very large place 'the river' occupied in all men's minds, but after a few months of life on its banks it was hardly less to me than to others, and I experienced a kind of shame when I recalled my former want of reverence, as if I had made a jest of something sacred. Nor to this day can I think of the Patagonian river merely as one of the rivers I know. Other streams, by comparison, seem vulgar, with no higher purpose than to water man and beast, or to serve, like canals, as a means of transport." So powerfully did the river impress the native minds that they became incapable of imagining any place to be habitable without it.

In one chapter we have an account of the habits of several breeds of dogs. A Scotch collie was found to take kindly to the wild life in the desert and soon became the leader of the ordinary dogs. But four pure-breed grayhounds, when tired of moping about the house, would take to the desert and course on their own 